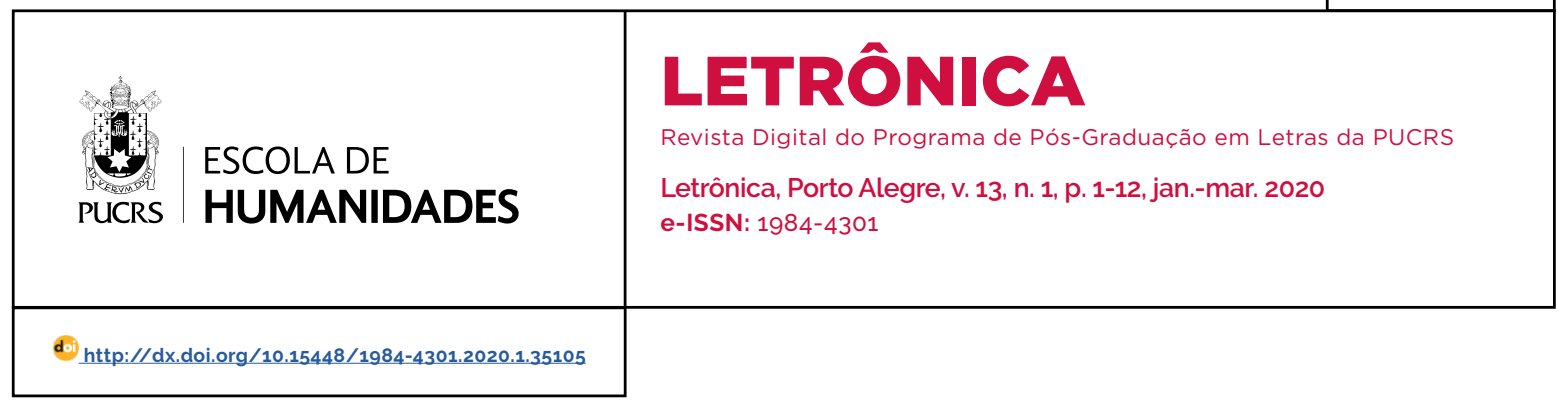

\title{
Maria Firmina dos Reis: intérprete do Brasil
}

\author{
Maria Firmina dos Reis: a Brazilian Translator
}

\section{Regia Agostinho da \\ Silva ${ }^{1}$ \\ orcid.org/0000-0001-9137-761X \\ ruaformosa@hotmail.com}

\section{Raffaella Andréa \\ Fernandez ${ }^{2}$}

orcid.org/0000-0003-4459-5977

raffhitas@gmail.com

Recebido em: 30 jul. 2019.

Aprovado em: 9 dez. 2019.

Publicado em: 7 abr. 2020

\section{(c) (i)}

Artigo está licenciado sob forma de uma licença Creative Commons Atribuição 4.0 Internacional.
Resumo: O presente artigo pretende analisar como a escritora negra maranhense Maria Firmina dos Reis (1822-1917) ao publicar Úrsula (1859) construiu outra narrativa para se compreender o Brasil e a formação de seu povo. Ao positivar pela primeira vez na literatura brasileira o elemento negro, Maria Firmina constrói outra identidade brasileira, levando em conta os africanos e afrodescendentes em nosso País. Ao fazer tal composição, a autora insere na discussão de nossa formação uma forte critica à escravidão que fazia parte de seu mundo e ainda faz parte do nosso quando procuramos entender o que é o Brasil. Ao mesmo tempo, essa escritora, por tão longo periodo esquecida e subalternizada, também usa o romance como uma crítica ao patriarcado e à dominação masculina. Procuramos ao longo do artigo demonstrar como Maria Firmina dos Reis fez isso, ou seja, criou uma nova interpretação do Brasil, mais plural e democrática. Palavras-chave: Intérprete. Brasil. Escravidão. Mulheres.

Abstract: This paper sets out to analyze to what extent Maria Firmina dos Reis (1822-1917), an Afro-Brazilian writer from Maranhão State, having published her novel Úrsula (1859) created a different sort of narrative so as to understand Brazil's history and its people. By dwelling attention on African elements in her literary productions, Maria Firmina builds up another Brazilian identity, the one which takes into account not only Africans, but also African descendants in our country. In doing so, the author focuses upon the discussion of our formation with a strong criticism to the slavery period, which by the way was part of her world and is still part of ours when one tries to understand what Brazil is. At the same time, this long forgotten and subordinate Brazilian writer also used the aforementioned novel as a means of explaining and criticizing patriarchy and male domination. Throughout the paper, we seek to demonstrate how Maria Firmina dos Reis did so, that is, created a new interpretation of Brazil, a plural and democratic one. Keywords: Interpreter. Brazil. Slavery. Women.

\section{Introdução}

A atenção aos marcadores sociais das diferenças tornou-se o divisor de águas nas discussões contemporâneas sobre a performance literária nos países que passaram por processos de colonização. A ausência histórica de um contexto de representatividade e de proporcionalidade de vozes não brancas em espaços acadêmicos e de celebração têm suscitado um acalorado debate acerca do ofício da escrita. Partindo dos processos de criação de autores e de autoras negras em estado diaspórico baseados na pirâmide de opressões raciais e de gênero (SCOOT, 1995) e no processo de superação de identidades partidas, este texto colocará no debate uma voz subalternizada que reinterpreta o seu lugar social e histórico no Brasil. Trata-se da escritora Maria Firmina dos Reis (1822-1917).

\footnotetext{
Universidade Federal do Maranhão (UFMA), São Luís, MA, Brasil.

2 Universidade Federal do Rio de Janeiro (UFRJ), Rio de Janeiro, RJ, Brasil.
} 
Em um país de expressões culturais e étnicoraciais variadas e desiguais como o Brasil, tal preocupação apresenta-se como um desafio permanente, que necessita de novas reflexões e de novas proposições que orientem as transformações necessárias.

Assim, o modo como Firmina pensa seu lugar ou não lugar na sociedade brasileira acaba por articular uma reflexão conjunta sobre o negro em nossa sociedade, problematizando a participação de escritas e escritoras negras nos processos históricos, na luta por direitos e por mais visibilidade no campo da literatura nacional.

\section{Intérpretes do Brasil}

Octávio lanni explica assim a existência de um "chamado pensamento social brasileiro":

\begin{abstract}
O Brasil é um pais que se pensa contínua e reiteradamente. Tanto é assim, que pode ser visto como uma "fábrica" de explicações, uma coleção de interpretações compondo uma visão do país no curso da história. Simultaneamente, revela-se uma "incógnita sem fim", contínua e reiteradamente taquigrafada, com o que adquire fisionomia, expressão, colorido, sonoridade, harmonia, estridência. Mas também pode ser visto como uma "nebulosa" movendo-se no espaço e no tempo, ao acaso das forças sociais internas e externas. Eventualmente, revela-se uma larga narrativa atravessada por dilemas, impasses e perspectivas que o leitor vislumbre (IANNI, 2000, p. 72).
\end{abstract}

Segundo lanni a reflexão sobre o Brasil constrói uma narração coletiva, uma metanarrativa que atravessa internamente textos diferentes e põemnos em contato na base do comum interesse para a nação.

Os intérpretes do Brasil consagrados na historiografia brasileira são, majoritariamente, homens brancos. José Ricardo Martins, em texto instigante, faz uma breve análise sobre os intérpretes mais conhecidos, que são: Alberto Torres, Oliveira Vianna, Gilberto Freyre, Sérgio Buarque de Holanda, Raymundo Faoro, Florestan Fernandes, Nestor Duarte, Victor Nunes Leal, Gláucio Ary Dillon Soares, Simon Schwartzman e Jessé Souza. Ou seja, na seleção que o mesmo faz não figura uma única mulher (MARTINS, 2017). Talvez isso se deva ao que o autor entende como intérprete da nação:

\begin{abstract}
A riqueza dos diferentes intentos de explicar ou interpretar o Brasil, a partir da organização social e política, ou seja, a partir de suas organizações, seus atores e a distribuição do poder, está no fato de que estes são pensados a partir de diferentes ângulos do escopo ideológico. Uns são a partir de um ideário conservador, outros liberais e muitos deles a partir de uma visão marxista (MARTINS, 2017, p. 308).
\end{abstract}

Portanto para Martins, os intérpretes seriam aqueles que estariam interessados em entender a organização social e politica do Brasil, e fabricado grandes narrativas ensaísticas, principalmente, em relação à identidade nacional ou ao que nos tornaria brasileiros. Neste sentido, ele não vê nenhuma mulher exercendo esse papel, apenas cita Marilena Chaui nas considerações finais de seu artigo. Ora, mesmo que o texto de Martins seja valioso, ele não nos diz tudo sobre o que seria interpretar o Brasil e deixa de lado, como toda seleção, diversos autores, principalmente da própria literatura nacional, que poderiam figurar em sua lista e mesmo em seu conceito tradicional sobre o que seriam intérpretes da nação, como por exemplo, José de Alencar, que ao lançar Iracema- a lenda do Ceará (1865) tenta construir uma imagem de nacionalidade, de nascimento da nação brasileira através da junção entre portugueses e indios, mesmo que seja a india morta, Iracema (RIBEIRO, 1998).

Já José Carlos Reis em seu livro As identidades do Brasil: De Varhagen a FHC, publicado em 1999, faz uma seleção bastante tradicional de intérpretes, não aparecendo nenhuma mulher, muito menos uma mulher negra, posto que Reis também entende a noção de intérprete como aqueles que procuraram de alguma forma narrar a história do Brasil procurando um sentido de identidade, ou seja, do que seria ser brasileiro, analisando o passado e tentando construir de alguma forma o futuro.

No entanto José Carlos Reis abre espaço para a discussão de uma possivel inserção de outras identidades e de outros intérpretes quando afirma:

Pode-se pensar o Brasil de múltiplos modos e todo sustentáveis com uma argumentação coerente e reconhecivel. Há versões do Brasil de origem senhorial, burguesa, proletária, classe média, camponesa, sem-terra, paulista, 
mineira, nordestina, gaúcha, negra, indígena, feminina, gay, imigrante, migrante, caipira, urbana, suburbana, litorânea, sertaneja, oficial, marginal, militar, civil etc. A maioria delas ainda não foi formulada, pois o povo brasileiro foi silenciado e não efetivamente representado na vida intelectual e política ao longo dos seus cinco séculos de vida. Contudo, cada um desses personagens se sente "brasileiro" de um modo particular e conta suas experiências de forma diferenciada por meio de festas, poemas, quadros, músicas, tradições orais (REIS, 2007, p. XVII, grifo nosso).

Nossa intenção neste artigo é justamente trazer à lume interpretações outras sobre o Brasil que foram silenciadas ao longo do tempo e não efetivamente representadas, por isso não aparecem nas antologias sobre os intérpretes da nação. Para isso ampliamos o conceito de intérprete e pensamos Maria Firmina dos Reis como agente privilegiado para pensar nossa identidade sob outra ótica ${ }^{4}$, outra perspectiva, que é a de mulher negra, periférica escrevendo literatura no Brasil e de como a mesma percebia as relações de ancestralidade de matriz africana e identidades no período da escravidão do qual Maria Firmina dos Reis foi contemporânea .

A moderna concepção de História descreve a "realidade dos fatos" como um conjunto de textos que dialogam entre si constituindo um tecido incompreensivel em sua totalidade. Assim, a verdade histórica, pensada como única e inquestionável pela historiografia cientificista do séc. XIX apresentase na perspectiva da Nova História como um corpus múltiplo, um mosaico de verdades parciais constituidas a partir de lugares sociais definidos.

Para os historiadores modernos uma dada "realidade" só pode ser apreendida pelo filtro das diversas representações sociais constituídas ao longo do tempo (CHARTIER, 1988).

É inegável que toda produção humana, incluindo a artística, está inserida em um momento histórico de uma determinada sociedade. E, com a literatura, isso não poderia ser diferente. Nela, ficção e realidade se misturam e se confundem. A gênese do texto literário depende da habilidade de criação e invenção do seu autor, que buscará no imenso acervo, acumulado por suas experiências e vivências, o material que por meio da palavra será convertido em literatura.

Leyla Perrone-Moisés, em Flores da Escrivaninha, diz que "a literatura parte de um real que pretende dizer, falha sempre ao dizê-lo, mas ao falhar diz outra coisa, desvenda um mundo mais real do que aquele que pretendia dizer" (PERRONE-MOISÉS, 1990, p. 102), talvez por colocar em palavras o que se pensava ser indizivel. Para o bem e para o mal, a literatura "desvela" o mundo. Ora completa, harmonizando as lacunas do real e compensa o que falta para tornar a realidade satisfatória. Ora expõe cruamente, dolorosamente, as terriveis fissuras da realidade. A literatura sempre poderá nos dizer o que poderia ser, o que está oculto e o que foi silenciado e revelar uma outra história, diferente da versão oficial.

Esse aspecto da Literatura como um meio de revelação daquilo que está encoberto vai ao encontro do pensamento de Walter Benjamin, expresso nos estudos "Sobre o conceito de história", de 1940. Benjamin ressalta que o outro lado da história que clama por ser conhecido, uma vez que a "história oficial" apresenta uma visão unilateral; para "libertar" o passado é necessário trazer à luz a versão dos oprimidos, dos excluidos, é preciso dar voz aos vencidos.

Assim, para Benjamim, a história oficial é sempre reducionista e parcial. É uma história narrada sob um determinado viés, o daqueles que estão no poder. É uma história que perpetua o discurso dos vencedores. Dai o apelo benjaminiano para "escovar a história a contrapelo" (BENJAMIN, 1993. p. 225), anulando os efeitos da narrativa histórica dos grupos dominantes e afastando a catástrofe que seria o esquecimento.

Nesse processo de desnudamento do discurso histórico oficial, e contra o "esquecimento" desejado pelos opressores, a memória é um instrumento valioso na revelação da "facies hippocratica" da história. O poeta, assim como o historiador social

4 Aqui agradecemos a Rafael Balseiro Zin que entre conversas informais nos chamou a atenção para a possiblidade de pensarmos Maria Firmina dos Reis como intérprete do Brasil. Ele esboçou uma pequena introdução sobre o tema em: REIS, Maria Firmina dos. Úrsula Porto Alegre, RS: Zouk, 2018. 
é o sujeito que não "estabelece uma relação empática com o vencedor" (BENJAMIN, 1993) e não participa do "cortejo triunfal" em que são carregados os despojos que chamamos "bens culturais". Ele é o flâneur que tudo observa e expõe na sua poesia as ruinas e os testemunhos de barbárie perpetrados pela classe dominante.

Se ao lado da história e memórias oficiais existe também uma história e memória secundárias, forjadas na contramão do discurso hegemônico, o poeta, como o historiador, é aquele que também narra os acontecimentos. Nessa narração, "memória" e "esquecimento" se alternam e se combinam, são faces da mesma moeda. O poeta, ao narrar a sua experiência dos fatos sociais e históricos por meio de sua poesia, não envereda pela autobiografia ou pela historiografia, antes resgata o discurso oculto dos oprimidos.

O papel do poeta é, portanto, revelar por meio da alegoria da escrita poética a "facies hippocratica" da história como paisagem original cristalizada. Será, então, por meio da escrita - espaço privilegiado da alegoria - que o historiador retirará a máscara mortuária do passado, expondo o discurso opressor da classe dominante. O poeta, assim como historiador e o trapeiro, recolhe das ruinas e do lixo da sociedade a matéria do seu trabalho.

A memória sempre foi uma preocupação do ser humano desde o início da civilização: fixar o passado, além de atar o homem e a sociedade à segurança de uma origem conhecida (ou construida), procura também possibilitar uma compreensão da cadeia de causalidades que constitui o universo presente (LE GOFF, 2013)

Manter a memória viva significa garantir uma sobrevivência no tempo. Por ter consciência de sua mortalidade o homem procura meios de não cair no esquecimento que representa a consumação final da morte: o desaparecimento definitivo do "ser". No contexto homérico, o desejo de permanência na memória ultrapassa, até mesmo, o desejo de sobrevivência no mundo: a excelência do herói residia no encontro com a morte nos campos de batalha, gestos que visavam à elevação do nome do herói a um plano acima do humano, pelo viés da memória social.

Cabe, também, destacar que esse movimento de perpetuar, esquecer e (re)inventar, descrito acima, define a própria natureza da imagem que uma sociedade faz de si mesma: a identidade social sempre imita o traçado da memória e também é constituída da matéria da lembrança, do esquecimento e da mentira (POLLAK, 1989).

A memória não pode ser vista simplesmente como um processo parcial e limitado de lembrar fatos passados, de importância secundária para as ciências humanas. Trata-se da construção de referenciais sobre o passado e o presente de diferentes grupos sociais, ancorados nas tradições e intimamente associados a mudanças culturais.

O conceito de memória está estreitamente ligado à história, que se confunde com ela e, ao mesmo tempo, cria-se a partir dela; para alguns, a antecede. As relações entre memória e história, e o conjunto de atos individuais e coletivos que lhes dão materialidade e espessura politica, delimitam um amplo espectro de abordagens historiográficas. As fendas, lacunas e silêncios que são objetivamente irrecuperáveis, pois faltam fontes documentais para isso, podem ser preenchidas com a literatura.

Fazer isso é tentar ler a História do Brasil e de sua formação e identidade em uma outra perspectiva, aquela dos agentes silenciados e/ ou não reconhecidos como tal. Vamos a elas.

\section{Maria Firmina dos Reis: Brasil afrodescente}

Maria Firmina dos Reis nasceu em São Luís do Maranhão, em 11 de março de 1822, no bairro de São Pantaleão. Morreu em 1917, na vila de Guimarães, interior do Estado, local onde passou a morar a partir dos cinco anos de idade.

Iniciou sua carreira literária com a publicação do romance Úrsula em 1859. Escritora, negra, antiescravista, professora, responsável pela fundação da primeira escola mista, para meninos e meninas, no Maranhão. Publicou, talvez, o primeiro romance de autoria feminina no Brasil (DUARTE, 2004).

O Maranhão do século XIX se configurava como umas das províncias de maior contingente escravo do país. Segundo um levantamento de 
1821, estimou-se que dos 152.893 habitantes da província, mais da metade eram escravos (GORENDER, 1978). Isso se devia ao quadro econômico que a compunha. Desde a criação da Companhia de Comércio do Grão-Pará Maranhão, criada pelo Marquês de Pombal, em 1755, a província teve uma entrada maciça de africanos escravizados. Nesse momento, a economia do Maranhão baseava-se como nas demais províncias do País, na agricultura voltada para agroexportação. No caso específico do Maranhão, a economia predominante foi a produção de algodão, na qual o trabalho escravo foi sua base de sustentação. As outras duas produções, de arroz e de açúcar, também se baseavam no trabalho escravo (FARIA, 2005).

No início do século XIX, a economia maranhense vivenciou aquilo que Celso Furtado denominou como "uma falsa euforia", (FURTADO, 2009), já que desestruturação americana, por conta da guerra civil, a economia maranhense ocupa um lugar de destaque nas exportações do País, enriquecendo, dessa forma, sua elite branca e escravocrata.

É nesse contexto que Maria Firmina dos Reis, irá publicar sua principal obra, Úrsula, em 1859, periodo pouco posterior à proibição do tráfico transatlântico de escravos, a Lei Eusébio de Queiroz de 1850.

O romance de Maria Firmina centra-se em uma narrativa romântica, na qual o jovem mancebo Tancredo, apaixona-se por Úrsula, a heroina do romance, pobre, e órfã donzela. Essas duas personagens, ao longo da narrativa serão ajudadas pelos personagens cativos que, muitas vezes, roubam as cenas. Percebemos, dessa forma, como Maria Firmina dos Reis constrói uma narrativa na qual o narrador onisciente discute a temática da escravidão e insere a temática antiescravista na província já em 1859

Maria Firmina, assim como muitas escritoras do século XIX, passou muito tempo no ostracismo, sendo "resgatada", por José Nascimento Morais Filho em 1975 na sua obra Maria Firmina: fragmentos de uma vida (MORAIS FILHO, 1975) onde o autor reúne escritos de Maria Firmina em alguns jornais, depoimentos de ex-alunos e alunas de Firmina e reedita os contos "A escrava" e "Gupeva". No mesmo ano, Horácio de Almeida reedita Úrsula, em edição fac-símile.

O romance Úrsula, como também o conto "A Escrava", nos ajudam a entender a lógica social da vida desses cativos, pelo menos através do ponto de vista e do olhar de Maria Firmina dos Reis, que inserida em seu contexto social, pode nos auxiliar, a saber um pouco mais sobre a vida dos mesmos. Podemos perceber claramente que no romance Úrsula, os três personagens escravos: Túlio, preta Suzana e Antero, falam sobre a escravidão em uma perspectiva de crítica, falam também da saudade da África, da diáspora. Preta Suzana fala da saudade que sente de sua terra natal:

\begin{abstract}
- Sim, para que estas lágrimas?!... Dizes bem! Elas são inúteis, meu Deus; mas é um tributo de saudade, que não posso deixar de render a tudo quanto me foi caro! Liberdade! Liberdade... ah! eu a gozei na minha mocidade! - Túlio, meu filho, ninguém a gozou mais ampla, não houve mulher alguma mais ditosa do que eu. Tranquila no seio da felicidade, via despontar o sol rutilante e ardente do meu país, e louca de prazer a essa hora matinal, em que tudo se respira amor, eu corria às descarnadas e arenosas praias, e ai com minhas jovens companheiras, brincando alegres, com o sorriso nos lábios, a paz no coração, divagávamos em busca das mil conchinhas, que bordam as brancas areias daquelas vastas praias (REIS, 2004, p. 115).
\end{abstract}

A África construida por Maria Firmina dos Reis é um lugar de liberdade, terra fértil, mãe dadivosa. Maria Firmina dos Reis imbuida do "instinto de nacionalidade" (ASSIS, 1959) como todos os românticos, no entanto, subverte o conceito, pois cria uma ideia de pátria e nação para a África. A nacionalidade que Maria Firmina cria, ou tenta criar, é uma nacionalidade africana como se ao formular um conceito de nação ou pátria para a África colocasse a região em igualdade à nacionalidade brasileira. Os cativos tinham um passado, uma História, uma família, uma pátria, assim como os brasileiros, assim como os europeus. São vários os momentos nos quais os personagens cativos se referem à África como sua pátria. Maria Firmina inaugura, assim, um outro olhar sobre a África, que não o de barbárie e selvageria, já que a ideia de uma África como pátria, transforma o continente inteiro em uma só unidade e o qualifica como lugar civilizado. Para 
Maria Firmina dos Reis, bárbaros eram aqueles que haviam transformado outros semelhantes em escravos, como nos informa essa passagem do romance, na fala, mais uma vez, de preta Suzana:

Ah meu filho! Mais tarde deram-me em matrimônio a um homem, que amei como a luz dos meus olhos, e como penhor dessa união veio uma filha querida, em quem me revia, em quem tinha depositado todo o amor da minha alma: - uma filha, que era a minha vida, as minhas ambições, a minha suprema ventura, veio selar a nossa tão santa união. E esse país de minhas afeições, e esse esposo querido, essa filha tão extremamente amada, ah Túlio! Tudo me obrigaram os bárbaros a deixar! Oh! Tudo, tudo até a própria liberdade! [...] Quando me arrancaram daqueles lugares, onde tudo me ficava- pátria, esposo, mãe e filha, e liberdade! Meu Deus! O que se passou no fundo da minha alma, só vós o pudeste avaliar (REIS, 2004, p. 115, grifo nosso).

A ideia de Maria Firmina sobre o que seria a barbárie vai contra muito do que estava disseminado no mundo ocidental e sobre a evolução da humanidade que lia os povos das Américas e da África como povos inferiores, bárbaros e selvagens. (SCHWARCZ, 2018.). Maria Firmina invertia a pirâmide e colocava aqueles que escravizavam outros como bárbaros. Esses sim eram os selvagens.

A civilidade, a nobreza, o bom caráter aparece em outro personagem cativo, no capítulo "Duas almas generosas", título sugestivo. Túlio salva o jovem mancebo Tancredo, que ao cair do cavalo, se encontra desmaiado. Vejamos como Maria Firmina dos Reis apresenta o jovem Túlio:

Nesse comenos alguém despontou longe, e como se fora um ponto negro no extremo horizonte. Esse alguém, que pouco e pouco avultava, era um homem, e mais tarde suas formas já melhor se distinguiam. Trazia ele algo que de longe mal se conhecia, e que descansando sobre um dos ombros, obrigava-o a reclinar a cabeça para o lado oposto. Todavia essa carga era bastantemente leve- um cântaro ou uma bilha; o homem ia sem dúvida em demanda de alguma fonte (REIS, 2004, p. 21, grifo nosso).

Firmina constrói a imagem do escravo em uma outra perspectiva, visto que o escravo de Firmina é aquele que tem individualidade, que é colocado em pé de igualdade com os personagens brancos. O escravo de Firmina, não é vítima da escravidão, passivo diante da sociedade escravocrata. Charles Martin tem razão ao falar que Maria Firmina construiu "uma rara visão de liberdade" (MARTIN, 1988) no movimento ela faz em colocar o branco e o negro em condição de igualdade. Ao descrever o ponto negro como um homem, antes de dizer que o mesmo era um escravo, Firmina humaniza o ser escravizado.

O escravo construido por Firmina é, antes de tudo, aquele que fala da África, que só reconhece a verdadeira liberdade no tempo em que vivia naquela África saudosa e nostálgica.

Maria Firmina, ao construir essa imagem de pátria África, a constrói como o avesso do que era o Maranhão e por extensão o Brasil; a África de Maria Firmina dos Reis era uma África sonhada, idealizada, mas que tinha como princípio a liberdade.

Na mãe África inventada de Maria Firmina, as relações de escravidão dentro do próprio continente africano não existiam. A pátria era uma mãe, boa, que perdia seus filhos levados pela ganância dos escravocratas. Até que ponto Maria Firmina sabia sobre o continente africano do século XIX é dificil responder. O que sabemos, com certeza, é que a escritora utiliza dessa imagem para recriar o avesso do País, na pátria ausente havia liberdade. Essa imagem formada, construida ou idealizada, essa África sonhada era o território e o lar daqueles cativos que clamavam contra a escravidão.

Ainda sobre a questão da igualdade entre brancos e negros a passagem que segue é fundamental:

\begin{abstract}
O cavaleiro começava a coordenar suas ideias, e as expressões do escravo, e os serviços que the prestara tocaram-lhe o mais fundo do coração. É que em seu coração ardiam sentimentos tão nobres e generosos como os que animavam a alma do jovem negro: por isso, num transporte de intima e generosa gratidão, o mancebo, arrancando a luva, que lhe calçava a destra, estendeu a mão ao homem que o salvara (REIS, 2004, p. 25).
\end{abstract}

Ao retirar sua luva para estender sua mão destra a Túlio, Maria Firmina iguala mais uma vez brancos e negros, proprietários e escravos, colocando até o pêndulo da balança maior para o escravo, já que é Tancredo, o branco, que tem um coração tão bom como o do escravo. O ponto 
de referência da bondade e da generosidade não está no personagem branco, e sim no negro, no escravo. O gesto de dá ao escravo a mão e a destra mais uma vez sela o sentido de igualdade entre os dois. O gesto é visto com espanto por Túlio, que não acredita que o branco esteja the dando a mão para um aperto entre iguais e acaba beijando-a, mas o narrador já os igualou, e até já provocou o leitor ao fazer a comparação da bondade e da generosidade partindo de Túlio e não de Tancredo. A primeira alma generosa é a de Túlio, o escravo.

Outra passagem importante na qual percebemos certo sentimento de superioridade africana está na fala do escravo velho Antero na qual ele relembra como eram as festas na sua pátria.

- Pois ouça-me, senhor conselheiro: na minha terra há um dia em cada semana, que se dedica à festa do fetiche, e nesse dia, como não se trabalha, a gente diverte-se, brinca, e bebe. Oh! Lá então é vinho de palmeira mil vezes melhor que cachaça, e ainda que tiquira (REIS, 2004, p. 208).

O escravo Antero é apresentado na narrativa como dado ao "mau-hábito" da bebida alcoólica, por isso, um ser em degradação, que pedia a um e a outro dinheiro para matar o vício. As lembranças são do velho escravo Antero, de seu tempo, da época em que trabalhava e, portanto, podia custear a sua bebida. Na pátria onde podia beber em dias festivos, onde a própria bebida tinha outro significado, que era o da festa, a celebração que Maria Firmina chama de fetiche, mas na qual a qualidade da bebida extraida do vinho da palmeira era muito melhor do que a encontrada no Brasil. Mais uma vez, a África aparece como o avesso do que aqui era encontrado, era a pátria da liberdade, da festa, do fetiche, da bebida com um significado religioso e não de degradação, como o álcool tinha se tornado para o velho Antero.

Como já falamos aqui em outro momento, a África de Maria Firmina dos Reis, embora idealizada, era uma África que continha nobreza e liberdade; era uma África mãe, que vira roubados seus filhos para a escravidão no novo mundo.

Ao construir essa imagem, Maria Firmina acaba por valorizar a cultura africana em nosso País, inaugurando assim, uma voz dissonante de tudo o que estava colocado na literatura brasileira do periodo e construindo a visão de um País afrodescendente, no qual as culturas de negros e brancos, assim como dos indigenas, visto que Maria Firmina também escreveu uma novela indianista chamada "Gupeva" (1861), se misturam e se igualam.

Firmina descentraliza o discurso branco, masculino e dominante do seu tempo para construir em seu romance, outra interpretação do Brasil, na qual o elemento negro tem suma importância. Para Cristiane Navarrete Tolomei:

\begin{abstract}
Dessa forma, conseguindo romper com o racismo institucionalizado pelo sistema-mundo moderno/colonial, Firmina exerce uma prática de escrita feminina sociopolítica, desconstruindo o discurso dominante e redirecionando o lugar de enunciação ao documentar, pelo viés literário na imprensa maranhense, as violências da representação e da opressão, acima de tudo, sobre os sujeitos negros escravizados no Brasil (TOLOMEI, 2019, p. 159).
\end{abstract}

Ainda existe no romance outra interpretação do Brasil, pelo viés de outros setores oprimidos que são as mulheres do século XIX.

\section{As mulheres em Úrsula}

Cinco mulheres importantes aparecem no romance de Maria Firmina, seriam: a mãe de Tancredo, que a autora não nomeia, a mãe de Úrsula, Luísa B; Adelaide, noiva de Tancredo e depois esposa de seu pai; Preta Suzana; e Úrsula.

A mãe de Tancredo aparece, na narrativa, pelas memórias do filho: mãe honesta, boa e virtuosa, que tudo sofreu da tirania do marido em nome do filho, por isso, diz Tancredo:

\footnotetext{
Não sei por que, mas nunca pude dedicar a meu pai amor filial que rivalizasse com aquele que sentia por minha mãe, e sabeis por quê? É que entre ele e sua esposa estava colocado o mais despótico poder: meu pai era o tirano de sua mulher; e ela, triste vitima, chorava em silêncio e resignava-se com sublime brandura (REIS, 2004, p. 60).
}

Ao construir a imagem da mãe de Tancredo como alguém que sofre a tirania da dominação masculina (BOURDIER, 2002), Firmina combate em outra frente, que é a das relações de gênero 
que estão colocadas no periodo (SCOTT, 1995). As mulheres de elite, que era o caso da mãe de Tancredo, mulher de um fazendeiro, tinham um espaço muito delimitado dentro do Brasil do século XIX, sendo muito subjugadas ao poder despótico dos homens.

O mesmo acontecia à mãe de Úrsula, Luisa B., vítima de todos os infortúnios e tristezas: paralítica, dependente da ajuda e dos cuidados da filha Úrsula. Viúva de um marido assassinado pelo próprio irmão, vítima do amor incestuoso do mesmo, o comendador Fernando P.

O marido de Luisa $B$, também não se mostrou benevolente com a mesma, visto que o marido Paulo B. se mostrou um péssimo cônjuge. mudando apenas após o nascimento de sua filha Úrsula, quando no dizer de Luísa B., já seria tarde demais, porque seu assassinato já estava para acontecer.

Luísa B., em seus últimos momentos de agonia sobre a terra, ainda teve a visita do irmão, Fernando, que acabou de matá-la, ao afirmar que pretendia desposar sua filha. Isso foi um golpe fatal para a desventurada mãe que nada mais tinha, a não ser o amor materno pela filha.

Essas construções contribuem para que se entenda como Maria Firmina dos Reis pintou seus quadros de mulheres, que embora resignadas e sofridas, servem para denunciar a tirania à qual algumas mulheres estavam submetidas: as mulheres de fazendeiros, de senhores de canade-açúcar e do algodão, submetidas ao domínio patriarcal, mas que, narrados seus sofrimentos, poderiam levar os leitores e leitoras de seu tempo à reflexão e, talvez, à mudança de olhar e atitude sobre elas. Como aponta Roger Chartier:

As fissuras que racham a dominação masculina não assumem todas as formas de dilacerações espetaculares nem se exprimem sempre pela irrupção de um discurso de recusa ou rebelião. Muitas vezes elas nascem dentro do próprio consentimento, reutilizando a linguagem da dominação para fortalecer a insubmissão (CHARTIER, 1994, p. 109).
Outro exemplo importante no texto da denúncia de Maria Firmina contra a sociedade patriarcal está na fala de Úrsula ao se comparar ao negro Túlio: "E Úrsula invejava vagamente a sorte de Túlio e achava mor ventura do que a liberdade poder ele acompanhar o cavaleiro" (REIS, 2004, p. 42). Túlio ao ser alforriado por Tancredo e por ser homem podia acompanhar o mesmo para onde esse fosse. Para as mulheres, de elite ou de familias de elite, como era o caso de Úrsula, isso era vetado. Ao invejar a sorte de Túlio alforriado, a autora coloca que a situação das mulheres de elite no século XIX se assemelhava um pouco a vida dos cativos, visto não terem liberdade de ir e vir, muito menos ao lado de um rapaz com o qual não tivessem compromisso firmado (SAFFIOTI, 2013).

Mesmo a personagem feminina que aparece como uma espécie de vilã na narrativa, Adelaide, noiva de Tancredo, que traí o pretendente e acaba se casando seu pai, também pode ser lida como uma personagem vítima da vilania patriarcal. Era uma moça pobre. A priori, o pai de Tancredo, não havia concordado com o filho. Depois, talvez levado pelas artimanhas da moça, acaba desposando-a. Nesta trama, em particular, podemos fazer um exercício de entender a lógica social dos agregados das fazendas. Adelaide era órfã, pobre, afilhada da mãe de Tancredo e sabia que muito dificilmente conseguiria um casamento vantajoso naquela sociedade marcada pela hierarquia social e de gênero. Acaba desposando o pai, talvez como forma de ascender socialmente. Tancredo só pode ler tal procedimento como vilania e traição e nunca como tática de sobrevivência feminina, afinal, ele é homem, branco e herdeiro. Qualquer ato de insubordinação feminina seria lido por ele, como ato de traição5.

A última personagem feminina que iremos tratar, com certeza, é a mais aviltada da narrativa: a escrava velha preta Susana.

Susana é uma personagem fundamental para entendermos o discurso antiescravista de Maria Firmina dos Reis e como a autora se preocupou

\footnotetext{
5 Sobre as relações e jogos políticos entre senhores proprietários e agregados ver Sidney Chalhoub em "Diálogos politicos em Machado de Assis", onde o autor defende a tese de que os personagens agregados e femininos na obra machadiana estavam sempre em luta pela sobrevivência em uma sociedade escravocrata e patriarcal como a brasileira do século XIX. Acreditamos que tal raciocínio possa ser usado para compreender as atitudes da personagem Adelaide em Úrsula, ver: CHALHOUB, Sidney. Diálogos políticos em Machado de Assis. In: CHALHOUB; PEREIRA (org.) A história contada: Capítulos de História Social da Literatura no Brasil. Rio de Janeiro: Nova Fronteira, 1998.
} 
ao longo do romance em discutir a escravidão.

Susana funciona como uma espécie de memorialista, tratando do passado ancestral e do movimento de diáspora dos africanos para o Brasil. Ao contrário de Túlio, que pensava a África como um lugar de origem dos seus ancestrais, Suzana é uma negra cativa que passou pelo processo do tráfico negreiro. Por isso, sua fala no romance é eivada de saudade da África e de amargura ao lembrar-se do processo violento que a trouxe ao Brasil.

Escrava de Luísa B., magra, descarnada, mesmo sendo escrava de uma senhora considera bondosa, preta Suzana traz, no corpo definhado, as marcas dos grandes sofrimentos que viveu por conta da escravidão.

Ao criar a personagem preta Suzana, Firmina tentou sensibilizar seus possiveis leitores e leitoras para a causa antiescravista. Ao colocar Susana para rememorar a África e sua liberdade, ela fala da possibilidade dos nativos nascerem livres e que, portanto, a escravidão não era um atributo natural.

É na rememoração dessa violência que Susana vai centrar sua fala sobre como foi seu translado para o Brasil:

Meteram-me a mim e a mais trezentos companheiros de infortúnio e de cativeiro no estreito e infecto porão de um navio. Trinta dias de cruéis tormentos, e de falta absoluta de tudo quanto é mais necessário à vida passamos nessa sepultura até que abordamos as praias brasileiras. Para caber à mercadoria humana no porão fomos amarrados em pé e para que não houvesse receio de revolta, acorrentados como os animais ferozes de nossas matas, que se levam para recreio dos potentados da Europa. Dava-nos a água imunda, podre e dada com mesquinhez, a comida má e ainda mais porca: vimos morrer do nosso lado muitos companheiros à falta de ar, de alimento e de água. É horrivel lembrar que criaturas humanas tratem seus semelhantes assim e que não lhes doa a consciência de levá-los a sepultura asfixiados e famintos! (REIS, 2004, p. 117).

\section{Essa passagem também pode nos enriquecer} de como se pensava a travessia nos navios negreiros, pelo menos no olhar de Maria Firmina dos Reis. Seu livro foi publicado em 1859, ou seja, nove anos após a abolição do tráfico com a Lei Eusébio de Queiroz, em 1850. Suzana é construida como uma personagem memorialista, na verdade, ela estava falando do processo violento de como ela foi trazida para o Brasil, talvez na tentativa da autora que isso não mais se repetisse.

Chegando às praias brasileiras, Suzana foi vendida para o comendador P..., um senhor de escravos bastante cruel:

O comendador P... foi o senhor que me esco-
lheu. Coração de tigre é o seu! Gelei de horror
ao aspecto de meus irmãos... os tratos, por que
passaram, doeram-me até o fundo do coração!
O comendador P... derramava sem se horrorizar
o sangue dos desgraçados negros por uma
leve negligência, por uma obrigação mais
tibiamente cumprida, por falta de inteligência!
E eu sofri com resignação todos os tratos que
se dava a meus irmãos, e tão rigorosos como
os que eles sentiam. E eu também sofri, como
eles, e muitas vezes com a mais cruel injustiça
(REIS, 2004, p. 118).

Ao abordar essa temática, Maria Firmina, mais uma vez, reafirma os horrores da escravidão, a crueldade de alguns senhores, tigres e verdugos. Mas também toca em pontos importantes como a questão da solidariedade entre os cativos. Para preta Susana, os outros cativos eram companheiros de infortúnio, eram irmãos, filhos da mesma pátria, que era a África. Esse sentimento de coletividade foi percebido por Maria Firmina dos Reis, talvez até para aprofundar sua tese de irmandade e semelhança entre todos, como filhos de Deus, por isso a escravidão, baseada na desigualdade entre semelhantes, não se sustentava.

Susana foi testemunha e vítima de outros horrores quando passou para o domínio de Paulo B..., esposo de Luísa B. e pai de Úrsula:

E ela chorava, porque doía-lhe na alma a dureza
de seu esposo para com os míseros escravos,
mas ele via-os expirar debaixo dos açoites os
mais cruéis, das torturas do anjinho, do cepo
e outros instrumentos de sua malvadeza, ou
então nas prisões onde os sepultava vivos,
onde, carregados de ferros, como malévolos
assassinos acabavam a existência, amaldiçoan-
do a escravidão; e quantas vezes aos mesmos
céus!... (REIS, 2004, p. 118).

Ao relatar os instrumentos de tortura utilizados pelo personagem Paulo B. para violentar seus escravos, Maria Firmina dos Reis está mais uma vez denunciando a vilania da escravidão. O castigo como anjinho, ou seja, um instrumento de 
suplício que comprimia os polegares dos cativos, e o cepo, um tronco grosso de madeira que o escravo trazia preso à cabeça, amarrado aos tornozelos por uma argola e, por fim, as prisões onde muitos morriam de fome (LARA, 1988). Ao denunciar tamanha violência na rememoração da preta Susana, Maria Firmina denuncia novamente a escravidão e a situação da mulher escrava negra, duplamente oprimida pela escravidão e por sua condição de mulher.

\section{Considerações finais}

Pensar Maria Firmina dos Reis como intérprete do Brasil é tomar a própria iniciativa da autora quando lança seu texto, um exercicio de subversão. Procuramos. ao longo deste artigo. demonstrar como Maria Firmina dos Reis, uma mulher negra e escritora, pode ser lida como intérprete da nação ao construir sua narrativa em Úrsula e inserir o elemento negro como positividade para a formação do povo brasileiro, colocando em discussão a escravidão e a dominação masculina, construindo uma interpretação inédita para o seu tempo.

Ao longo do redescobrimento de sua obra, Maria Firmina dos Reis garantiu, segundo Maria Helena Toledo Machado, ser "hoje figura consolidada no panorama da literatura brasileira" (MACHADO, 2019, p. 93). Tal afirmação não soa exagerada visto que nos últimos quinze anos, desde a quarta edição de Úrsula, em 2004, pela editora Mulheres (REIS, 2004), Maria Firmina foi adquirindo visibilidade nacional, e até internacional. Redescoberta em 1975 por Nascimento de Morais Filho (MORAIS FILHO, 1975) com sua preciosa pesquisa Maria Firmina: Fragmentos de uma vida, e depois trazida à lume mais uma vez no centenário da Abolição em 1988, por Luiza Lobo, em uma terceira edição de Úrsula (REIS, 1988).

Ao ser lançado pela editora Mulheres, dirigida por Zahide Muzatti em parceria com a editora PUCMinas, o romance ganhou o mundo (REIS, 2004). Sendo alvo de diversas pesquisas acadêmicas em diferentes áreas do conhecimento como História, Sociologia e Letras. Foram feitas ao longo dos últimos anos várias dissertações de mestrado e teses de doutorado tratando do romance e da romancista (SILVA, 2013; ZIN, 2015; DIOGO, 2016).

$\mathrm{Na}$ edição de 2004 consolidou-se também a leitura do romance feita no posfácio por Eduardo de Assis Duarte Maria Firmina dos Reis e os primórdios da ficção afro-brasileira, onde o autor pleiteia para Maria Firmina o lugar de primeira escritora abolicionista do Brasil, seguindo a esteira do que já havia sido colocado por Charles Martin na terceira edição de Úrsula em seu prefácio "Uma rara visão de liberdade" (MARTIN, 1988).

Acreditamos que foi graças a quarta edição de 2004 e aos diversos movimentos de ressignificação do que seria ser negro no Brasil, aos movimentos políticos negros, espalhados por todo o pais, inclusive dos feminismos negros que a autora teve uma grande visibilidade nas últimas décadas, uma visibilidade jamais vista. Existem hoje, mais de dez edições do romance, inclusive com uma edição pela considerada maior editora do pais, Companhia das Letras, pelo selo Penguin Classics (REIS, 2018).

As novas edições contam com prefácios enriquecedores que aprofundam mais sobre a obra, como é o caso do texto de Rita Terezinha Schmidt; "Uma voz das margens: do silencio ao reconhecimento" que consta na edição da editora Zuck, de 2018, onde a autora coloca que "a leitura de Úrsula nos convoca a revisitar o passado e a fazer uma reflexão sobre o que fomos, o que somos e o que queremos ser enquanto partícipes de uma nação" (SCHMIDT, 2018).

Na esteira dessa colocação de Schmidt (2018), acreditamos que ao "complexificar" a noção de intérprete podemos inserir Maria Firmina dos Reis e demais autores e autoras que foram relegados ao esquecimento e/ou silenciamento, na empreitada de compreender o que é nosso País e, como vozes subalternizadas e consideradas periféricas podem enriquecer a discussão da construção da identidade brasileira. Oxalá, descubramos outras vozes que se juntem a de Maria Firmina dos Reis nessa tentativa. 


\section{Referências}

ASSIS, Machado de. Machado de Assis: crítica, notícia da atual literatura brasileira. São Paulo: Agir, 1959. p. 28-34. [1 ${ }^{\mathrm{a}}$ ed. 1873]. https://doi.org/10.30681/ 23588403 V11i012215225

BENJAMIN, Walter. Obras Escolhidas. Magia e técnica, arte e política: ensaios sobre literatura e história da cultura. Trad. Sérgio Paulo Rouanet, São Paulo: Brasiliense, 1985. v.1.

BENJAMIN, Walter. Obras escolhidas. Magia e técnica, arte e política. Ensaios sobre literatura e história da cultura. São Paulo: Editora Brasiliense, 1993. v.1.

BOURDIEU, P. A dominação masculina. 2.ed. Trad. de Maria Helena Kühner. Rio de Janeiro: Bertrand Brasil, 2002.

CHARTIER, Roger. A História hoje: dúvidas, desafios, propostas. Revista Estudos Históricos, Rio de Janeiro, v. 7, n. 13, 1994, p. 109.

CHARTIER, Roger. História Cultural: entre práticas e representações. Lisboa: Difusão Editora, 1988.

DIOGO, Luciana Martins. Da sujeição à subjetivação: A literatura como espaço de construção da subjetividade, os casos das obras Úrsula e A Escrava de Maria Firmina dos Reis. 2016. Dissertação (mestrado) - USP, São Paulo, 2016. https://doi. org/10.11606/d.31.2016.tde-01112016-103251

DUARTE, Eduardo de Assis. Maria Firmina dos Reis e os primórdios da ficção afro-brasileira [Posfácio]. In: REIS, Maria Firmina dos. Úrsula: A Escrava. Florianópolis: Ed. Mulheres; Belo Horizonte: PUC Minas, 2004. https://doi.org/10.11606/d.31.2016.tde-01112016-103251

FARIA, Regina Helena Martins de. Trabalho escravo e trabalho livre na crise da agroexportação escravista no Maranhão. 1998. Monografia (Especialização em História Econômica Regional) - Departamento de História, Universidade Federal do Maranhão, São Luis, MA, 1998. https://doi.org/10.24873/j. rpemd.2018.09.228

GORENDER, Jacob. O escravismo colonial. São Paulo: Editora Ática, 1992.

IANNI, Octavio. Tendências do pensamento social brasileiro. In: Revista Tempo Social, São Paulo, 12 (2), p. 57- 74, 2000. https://doi.org/10.1590/s010320702000000200006

LARA, Silvia Hunold. Campos da violência: escravos e senhores na Capitania do Rio de Janeiro, 17501808. Rio de Janeiro: Paz e Terra, 1988. https://doi. org/10.11606/d.8.2007.tde-10072007-113154

LE GOFF, Jacques. História e Memória. Campinas: Editora da Unicamp, 2013.

MACHADO, Maria Helena Pereira Toledo. Maria Firmina dos Reis: escrita intima na construção do si mesmo. Revista Estudos Avançados, 33, (96), USP, p. 92-108, 2019. https://doi.org/10.1590/s01034014.2019.3396.0007
MARTIN, Charles. Uma rara visão de liberdade. Prefácio. In: REIS, Maria Firmina dos. Úrsula. Rio de Janeiro: Presença Edições; Brasilia: INL, 1988, p. 9-14.

MARTINS, José Ricardo. Os intérpretes do Brasil: pensamento sociopolítico lastreado no fluxo de ideias, narrativas e realidades na busca de uma identidade nacional brasileira. Revista Tempo do Mundo, v. 3. n.1. jan. 2017. https://doi.org/10.5380/nep.v3i2.53518

MORAIS FILHO, José Nascimento de. Maria Firmina, fragmentos de uma vida. São Luís: COCSN, 1975.

PERRONE-MOISÉS, Leyla. Flores da escrivaninha. São Paulo: Companhia das Letras, 1990.

POLLAK, Michael. Memória, esquecimento, silêncio. Revista Estudos Históricos, Rio de Janeiro, v. 2, n. 3. 1989, p. 3-15.

REIS, José Carlos. As identidades do Brasil: de Varnhagen a FHC. Rio de Janeiro: FGV, 2007.

REIS, Maria Firmina dos. Úrsula. São Paulo: Penguin Classics Companhia das Letras, 2018.

REIS, Maria Firmina dos. Úrsula; A Escrava. Florianópolis: Ed. Mulheres; Belo Horizonte: PUC Minas, 2004.

RIBEIRO, Renato Janine. Iracema ou a fundação do Brasil. In: Marcos C. Freitas (org.). Historiografia brasileira em perspectiva. São Paulo: Universidade São Francisco/Contexto, 1998.

SAFFIOTI, Heleieth. A Mulher na Sociedade de Classes. Mito e Realidade. São Paulo: Editora Expressão Popular, 2013

SCHMIDT, Rita Terezinha. Uma voz das margens: Do silêncio ao reconhecimento. Prefácio. In: REIS, Maria Firmina dos. Úrsula. Porto Alegre: Zouk, 2018, p. 13-24.

SCHWARCZ, Lilia Moritz. O espetáculo das raças: cientistas, instituições e questão racial no Brasil (1870-1930). São Paulo: Companhia das Letras, 1993 https://doi.org/10.5585/eccos.n46.8915

SILVA, Régia Agostinho da. A escravidão no Maranhão: Maria Firmina dos Reis e as representações sobre escravidão e mulheres no Maranhão na segunda metade do século XIX. 2013. Tese (doutorado em História Econômica) - São Paulo, USP, 2013. https:// doi.org/10.11606/t.8.2013.tde-14032014-094659

TOLOMEI, Cristiane Navarrete; REIS, Maria Firmina dos. Decolonialidade e escrita abolicionista na imprensa maranhense oitocentista. Ex æquo, n. 39 , p. 153-168, 2019. https://doi.org/10.22355/exaequo.2019.39.10

ZIN, Rafael Balseiro. Maria Firmina dos Reis: a trajetória intelectual de uma escritora afrodescendente no Brasil oitocentista. 2015. Dissertação (mestrado) São Paulo: PUC-SP, 2015. 


\section{Endereço para correspondência}

Regia Agostinho da Silva

Universidade Federal do Maranhão

Av. dos Portugueses, 1966, Departamento de História, Sala do DEHIS

Bacanga, 65080-805

São Luis, MA, Brasil

Raffaella Andréa Fernandez

Universidade Federal do Rio de Janeiro

Av. Pedro Calmon, 550

Cidade Universitária, 21941-901

Rio de Janeiro, RJ, Brasil

\section{Regia Agostinho da Silva}

Doutora em História na universidade de São Paulo (2013). Possui mestrado em História pela Universidade Federal do Ceará (2002). Atualmente é professora da Universidade Federal do Maranhão. Professora permanente do Programa de Pós-Graduação em Letras - Mestrado Acadêmico da UFMA/Campus Bacabal. Tem experiência na área de História, com ênfase em História do Brasil Império, atuando principalmente nos seguintes temas: história e literatura, história das mulheres e história e escravidão.

\section{Raffaella Andréa Fernandez}

Bacharel e Licenciada em Ciências Sociais (CNPq / 2004) pela UNESP de Marília, quando iniciou seus estudos sobre Carolina Maria de Jesus e Esmeralda do Carmo Ortiz, desenvolvendo a monografia intitulada "Em todo e nenhum lugar: vozes da marginalidade". Em seguida realizou mestrado em Literatura e Vida Social (Capes/2006) pela UNESP de Assis com defesa da dissertação intitulada "Carolina Maria de Jesus, uma poética de residuos". Em 2010 recebeu o título de Licenciatura em Letras-Português/Francês da UNESP de Assis. Desenvolveu pesquisa de doutorado em Teoria e História da Literária (2015) no IEL-UNICAMP, com estágio de doutorado no Institute de Textes et Manuscrits Modernes (ITEM/ CNRS) na École Normale Supérieure de Paris (Capes-PDSE/2013) sobre os aspectos literários, dispersos nos manuscritos inéditos de Carolina Maria de Jesus. Atualmente é pós-doutoranda do Programa de Pós-Graduação em Ciência da Literatura da UFRJ (PNPD/Capes) e do Programa Avançado de Cultura Contemporânea (PACC-UFRJ), sob supervisão da Profa. Dra. Heloísa Buarque de Hollanda. É investigadora integrada ao CLEPUL (Centro de Literaturas e Culturas Lusófonas e Europeias da Faculdade de Letras) da Faculdade de Letras da Universidade de Lisboa (2014). 